\title{
CHEMICAL DEGRADATION AND PROCESSES OF EROSION OF POST-MINE TERRITORIES AFTER MINING EXPLORATION OF IRON ORE
}

\author{
Agnieszka Pusz' ${ }^{1}$, Dominik Rogalski' ${ }^{1}$ Anna Trawińska \\ 1 Warsaw University of Technology, Faculty of Building Services, Hydro and Environmental Engineering, \\ Nowowiejska 20, 00-653 Warsaw, Poland
}

Corresponding author's e-mail: dominik.rogalski.dokt@pw.edu.pl

Received: 2017.08 .25

Accepted: 2017.10.01

Published: 2017.11.01

\begin{abstract}
The subjects of this study were uncultivated mining waste heaps which are remnants of the territories abandoned after the exploration of iron ore. The aim of this analysis was the assessment of the influence of these objects on the soil located in the nearest surroundings, as well as estimation of the level of their degradation. It was ascertained that direct geomechanical degradation exists in the examined object, which is connected with soil profile destruction in consequence of transformation of hitherto existing geomorphological conditions, deformation of natural shape of territory, density of soil levels and deformation of the spatial layout. As a result of the examination, it was pointed out that chemical degradation as well as degradation of ecological structure occur on the analyzed territory. Progressing processes of water erosion on the side of waste heap are the consequence of improperly profiled, steep slopes causing the uncontrolled flow of rainwater, lack of flora and dense, micrograiny structure of soils which prevents the effective infiltration of water. Penetration of water into the ground causes the creation of channels which, in dry periods, can become additional pathways for the possible landslides.
\end{abstract}

Keywords: recultivation, water erosion, mine exploration of iron ore, post-mine territories, degradation, soil pollution

\section{INTRODUCTION}

Management of mining waste which could also result from the rendering and tooling accessible ore and additional concurrent minerals, was defined according to the regulation for prevention of environmental damage and their improvement as an activity creating the risk major damage to environment. They are created as a result of mine exploitation, occupying the surface in enormous amounts of land mass, causing the transformation of soil, leading to the disturbance of environmental balance, recession of many valuable species of soil flora and fauna and as well degradation of soil itself. They decrease the farm or forest's useful area as the result of unfavorable changes in the environment or inappropriately managed industrial activity [Regulation for protection of farm and forest grounds].
The mining wastes stored on heaps are in need of reclamation. In most cases, it leads towards the shaping of the surface and reconstruction of soil, through forestation and grass formation. A layer of plants limits the dusting from the object, stabilizes the soil and considerably improves the esthetic value as well as increases the number of green areas [Pancewicz 2009]. The small heaps in the shape of regular polygon or circular heaps which deform partially under the process of sedimentation are the most profitable for implementing [Maciejewska 2000]. Part of land mass transported to the waste heaps, depending on its characteristic, may be reused because some of the stored materials still carry useful mineral [Gabzdyl 1999]. The number of causes and mechanisms as well as natural and anthropogenic degrading characteristics of soil, create difficulties in arrangement of universal 
classification of degradation forms and threats towards surface soil. The factors influencing the soil as a result of exploitation of metal ore are: changes in moisture conditions, loss of useful values in the consequence of multi-territorial process of degradation, pollution by heavy metals, salinity or acidification, numerous structural transformations which are simultaneously the cause of plant destruction. At the same time, the soil is threatened by numerous geomechanical transformations, while the level of soil sensitivity on destruction depends on the individual features of each soil-type environment. Soil susceptibility to biodegradability and lack of early reclamation activities with regard to the executed extraction works, may in consequence lead toward the creation of soilless areas which should be reclaimed and brought into economy. The aim of the work was to estimate of the influence of unmanaged waste heaps after former mining exploitation of iron ore on the soil and the analysis of the level of their degradation.

\section{MATERIAL AND METHODS}

\section{The subject of study}

The subject of the study was dormant mine area after the finished exploitation of iron ore, located in north-eastern part of Starachowice, where two objects are located, constituting the subject of conducted analysis (Figure 1 and 2). The waste heaps are composed of the remains after the operation of the last productive iron ore mine "Nowa Majówka" [Adamczyk and Pastuszka 1984].

The semispherical waste heaps are $200 \mathrm{~m}$ in height, where it is possible to observe numerous erosive and land-slide processes. Objects are of characteristic brown colour, originating from iron located in subsoil formed on native grounds. Because the area is rich in low-percent bog iron ore dumps, all their intersection might be compose of homogeneous material. In mass materials stored on dumping grounds, clayey rock chips, limestone and traceable fossils in shapetraces of organism activity printed in the rock can be found. Unmanaged objects peak over the city, marking its existence in the local view and contrast with local mixed and coniferous forests (Figures 3 and 4). The bases of dumps are covered by countless number of plants bushes and trees, but closer to the top the dump is defor- ested. In the eastern part at the bottom of object A, damp terrains are located, whereas a private factory collecting recycled paper and local allotments is found in the surroundings of circular heap B. Dumping grounds are located in the distance of $300 \mathrm{~m}$ from each other.

\section{Examination methods}

Samples were taken from the depth of $0.25-0.50 \mathrm{~m}$ below ground level (BGL), according to PN-ISO 10381-2:2007 standard. Chemical markings were carried out in air dry samples of known hygroscopic humidity. Examinations were conducted according to the given methods: type of scent together with scale of intensity $(1$ - very weak, very low intensity, 2 - small, low intensity, 3 - medium, moderate intensity, 4 - strong, high intensity, 5 - very strong, very high intensity), granulometrical composition by sieve method and Casagrande's with modification by Prószyński, colour according to Munsell's atlas, $\mathrm{pH}$ in $\mathrm{H}_{2} \mathrm{O}$, according to $\mathrm{PN}-\mathrm{ISO}$ 10390:1997; electrolytical conductivity EC, according to PN-ISO 11265+ACI:1997, chloride contents, according to PN-ISO9297:1994, sulfate contents, according to PN-ISO 9280:2002, water-permeability of soil and ground was defined by the value filtration factor, according to PKN-CEN ISO/TS 17892-11:2009, contents of organic coal, according to $14235: 2003$, hydrolytic acidity and the sum of exchangables alkaline cations, according to Kappen's method [Ostrowska et al. 1991]. Soluble forms of iron were marked in three solvent extractions $\left(\mathrm{H}_{2} \mathrm{O}\right.$, $0,1 \mathrm{M} \mathrm{HCl}$ and $1 \mathrm{M} \mathrm{HCl}$ ) by colorimetrical method. Complete contents of cadmium, zinc, lead and iron were marked after mineralization according to PN-ISO 11466:2002 with the thermal spectrometry ICP-OES method, according to PN-EN ISO 11885:2009.

\section{RESULTS AND DISCUSSION}

\section{Identification of erosive processes}

Distinct erosive processes caused by the high speed flow of water on the unprofiled slopes were ascertained on the examined objects. High intensity of water erosion was observed particularly in the case of eastern slope of object B, which was devoid of plants and 


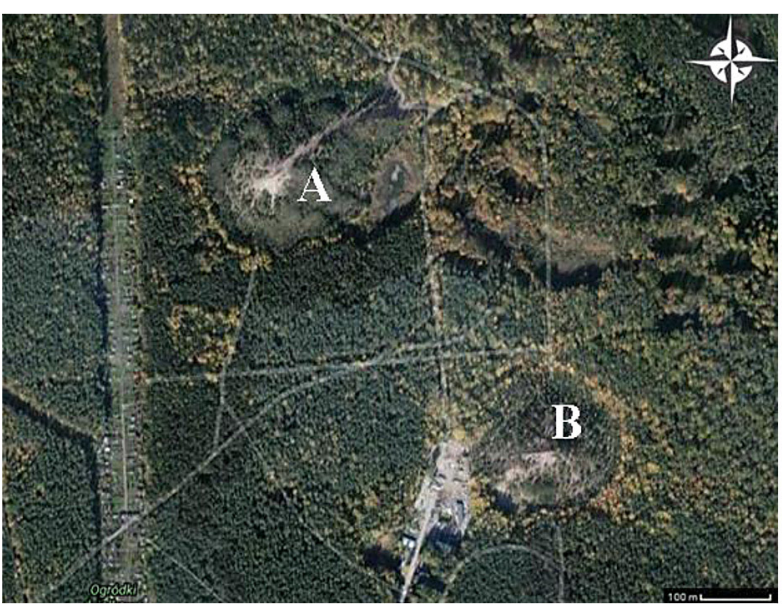

Figure 1. Location of the objects A and B
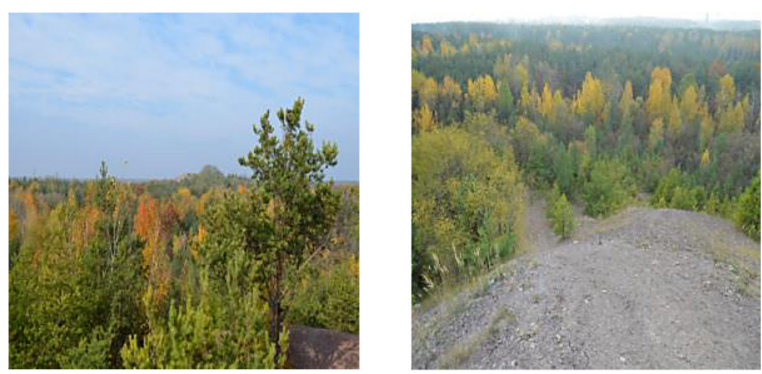

Figure 3. Top of object A

had convenient conditions for the uncontrolled water flow Figure 5.

Identification of the heap allowed to ascertain that one of the main elements causing water erosion, are water drops which hit the surface of the ground and create mud, which turns into dry shell when dried, creating difficulty in gas exchange in deposition of material. Dead ground structure of clay loam, in which particular elements closely adhere to each other, prevents the infiltration of rain water and causes water to penetrate the subsoil. It creates rill-marks, which in dry periods additionally creates trails for dried land slide (Figure 6). Micro-molecular structure of clay material, in the case of lack of rain, exhibits the tendency of cracking (Figure 7). Water gathers in the fissures created on the surface fault fissures gathers, which causes deformation and distortion of the slope with its subside and rock fall as well as transformation of earlier rillmarks into deep ravines (Figure 8). The lack of plants is also important. Plant cover absorbs some of the rain fall and simultaneously decreases the force of impact of the rain drops, slowing down the flowing stream on the ground. Thanks to the developed root system, it mechanically fixes soil

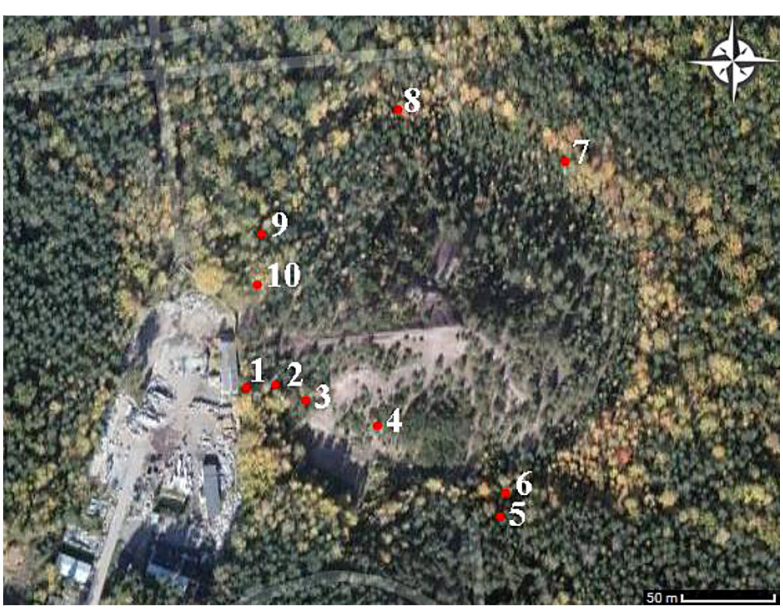

Figure 2. Location of sample points on object B
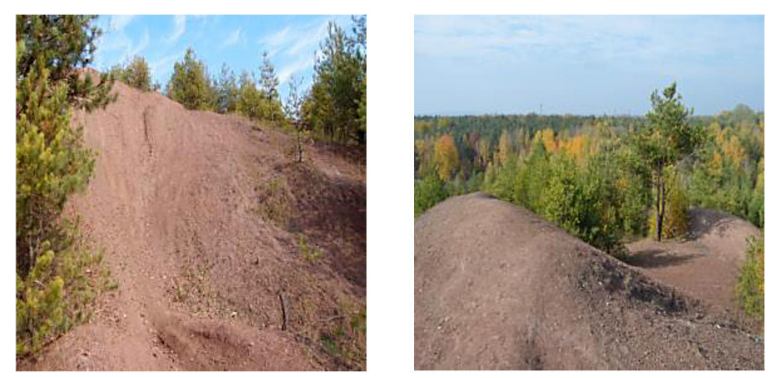

Figure 4. Top of object B

elements, which improves the profile structure and their retention ability [Karczewska 2012]. Plant community limits the amount and speed of melting waters. Turf corrects the physical and chemical characteristics of soil, being conductive in creating the pelletizing structure and reducing the washing-out ability of soil, while its surface elements counteract splashing of pieces and the change of water characteristic flowing down the surface [Józefaciuk A. and Józefaciuk C. 1996a]. In the case of the analyzed object, a complete lack of soil formation was observed on the convexoconcave slope, which increases the erosive processes causing intensive flow due to melting of snow cover. Water originating from snow-cover does not have the capability of infiltrating into frozen ground, which could become the cause of local floods in the spring-autumn season. Deposition of snow in rill-marks, thanks to its accumulation, demands longer period of time to melt than the snow-cover on the flat territories [Józefaciuk A. and Józefaciuk C. 1996b].

According to the classification proposed by Józefaciuk A. and Józefaciuk C. [1996b] and Karczewska [2012] the level of intensity of erosive effect on the analyzed object can be considered 
a)

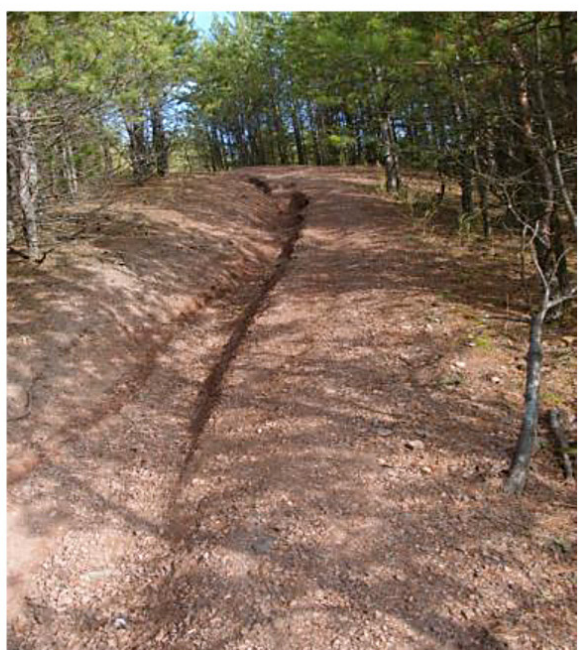

b)
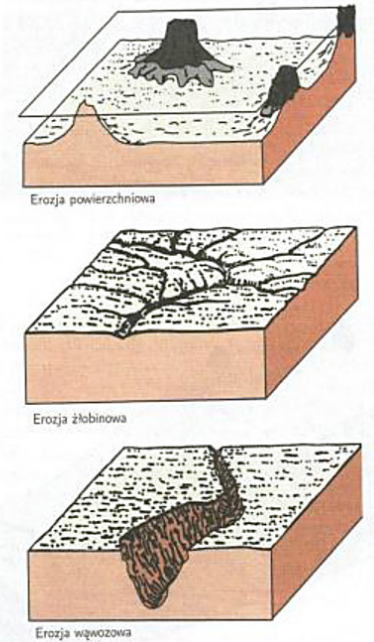

Figure 5. a) Erosion on heap B slope; b) Types of water erosion [Hillel 2008 modified]
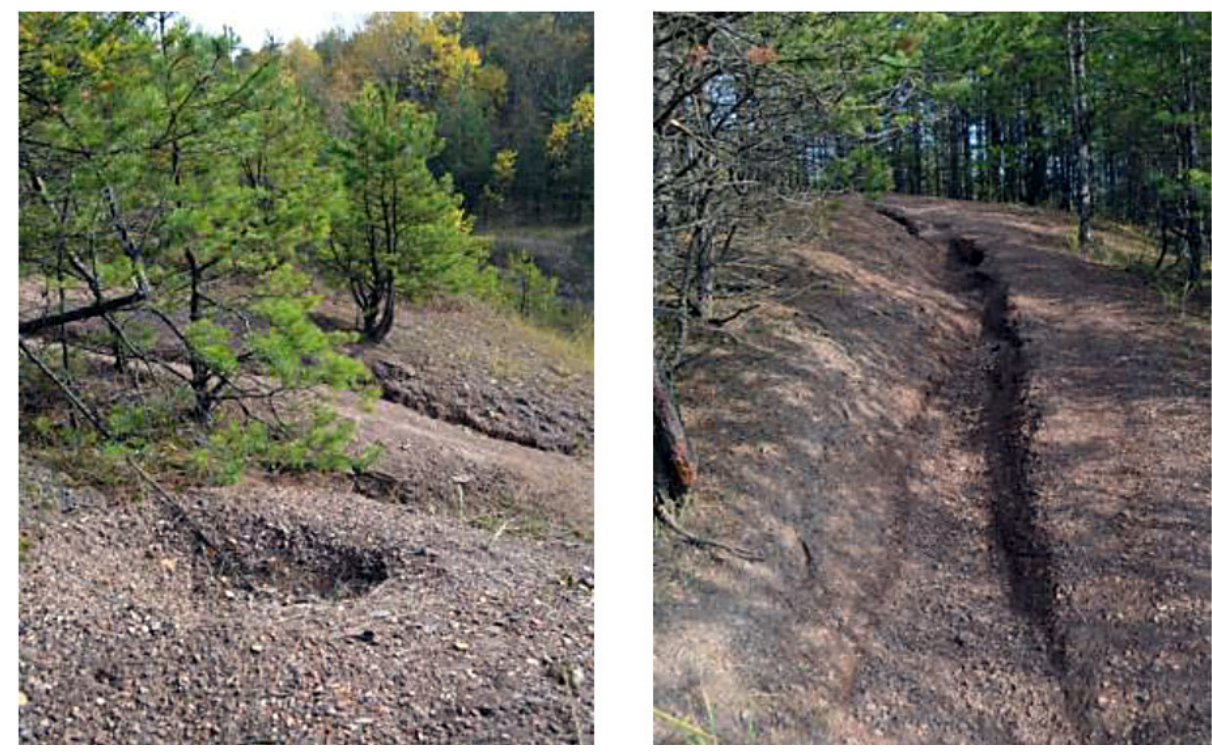

Figure 6. Erosion on heap B

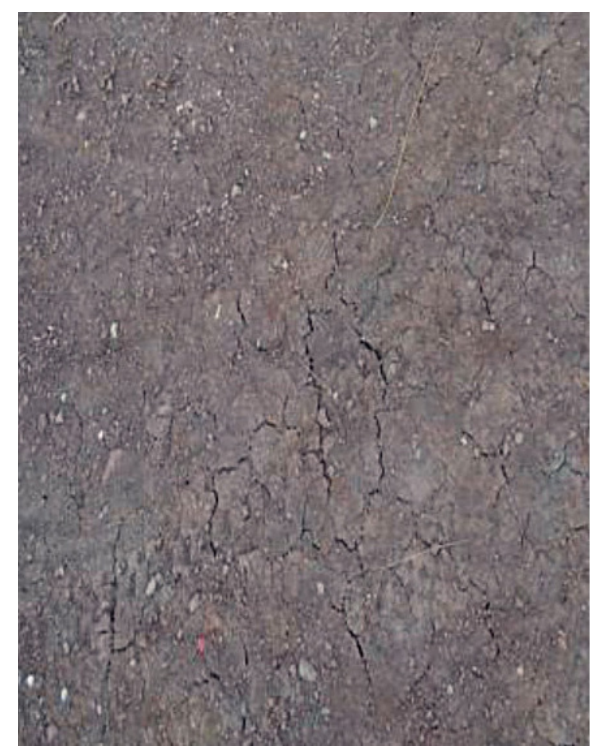

Figure 7. Cracks of dry clay material on the slope of heap B

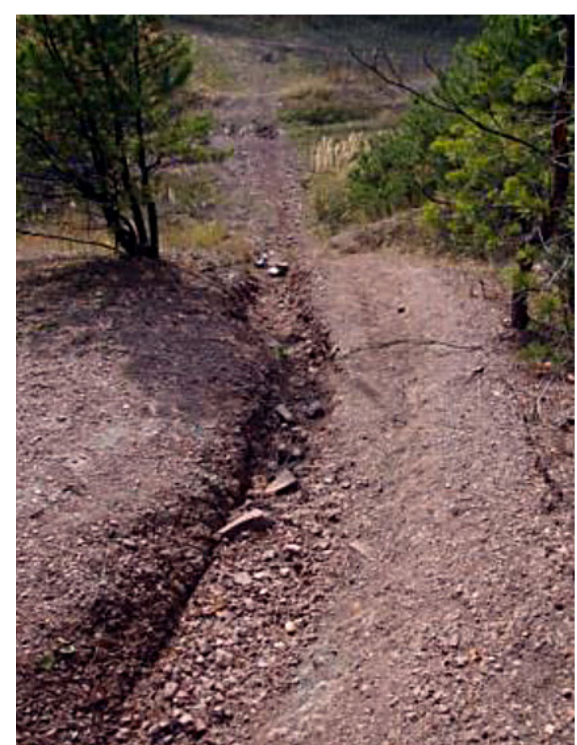

Figure 8. Movement of soil masses and chippings down along the slope of heap B 
as intensive, which indicates the depth of forming fault fissures reaching below endohumus level. As given by Józefaciuk A. and Józefaciuk C. [1996a] fault fissures are the cause of so called "dispersed surface soil ablation" on the slope which is based on the movement of soil particles and rock chippings in the stream of rain waters and melting snow. Initially, this process occurs as few centimeters of micro-rill-marks in the ground and leaching of singular, dissolving ingredients which with time intensifies, taking the forms of line-rill-marks that can be observed at present. The substance washed away from the slope accumulates at its base creating diversified alluvium. Erosion in the early stadium of development degrades the surface's most fertile layers of soil, but with time passing, the force of processes damage the deeper layers leading in consequence to the uncovering of roughly weathered bed rocks, turning these areas into wastelands [Uggla 1977].

\section{Physical and chemical characteristics of soil}

Immunity of ground environment to degradation is governed by many factors, both natural as well as anthropogenic. The most immune soils include dense-molecule clay and silt material with large number of flushed parts, but the least immune are the grounds created of sands which, with disadvantageous structure and lack of resources of feeding ingredients, are conducive to the intensive processes of destruction [Greinert 1998]. Thanks to the buffering and sorptive characteristic, soil accumulates large amounts of pollution which, because of the influence of a number of continued processes may change forms in which they occur. Pollution in the soil is being turned into sorption and precipitation, while the number of accumulated ingredients is growing together with the lowering of the level of thickness and homogeneity of graining. In consequence of bonding of pollutants into permanent phase, their negative reaction on the environment is being limited, and in some cases - completely eliminated [Karczewska 2012].

According to the Regulation of the Minister of the Environment of 1st September 2016 on conduct of the assessment of contamination of the surface of the earth, determinations of physicochemical characteristics of soil and contents of pollution was conducted on ground fractions (of diameter $<2 \mathrm{~mm}$ ), after separation on the sieve coarse-grained fractions $(>2 \mathrm{~mm})$. In the case of the examined samples, it was not stated whether coarse-grained fractions could be the source of pollution. That is the reason why they have not been analyzed separately. Table 1 presents the contents of fraction $>2 \mathrm{~mm}$, together with name of the material, colour and scent. The framing parts of soil mainly consisted of dry plant left-overs and rocks of different size bound with mining iron ore, the content which was different depending on the sampled places. Most of the samples taken from the examined object consisted of clay loam with diversified characteristic and different intensity of brown or gray-pink colour. Exceptions consisted of samples 7, 8 and 10 defined as loamy sand and sample 5 described as sand, which created environmental background.

On the basis of granulometric composition, the examined samples 1, 2, 3, 4, 6 and 9 were classified as heavy soils and the other samples with numbers 5, 7, 8 and 10 as light soils. The analyzed samples were marked organoleptically towards identification of the kind (specific, chemical scent, rotting, soil-smell) and intensity, which correlated with the colour of the examined samples. Scent, together with other physical characteristics, allowed to state the oncoming changes in soil environment samples 1, 3, 4 and also 9, 10 exhibited strong rotting scent resulting from the ongoing processes of decomposition of organic matter, all the rest were marked as having specific scent. Exception consisted of sample 5, so called "background", which was characterized by soilscent with specific dark-grey colour.

Table 2 contains the examination results of chosen physicochemical and chemical particulars of soil. The results obtained from the examination suggest that most of samples (with the exception of sample 5, so-called "background" with natural high level of acidity), exhibited neutral and of alkaligenous reaction. Such $\mathrm{pH}$ limits dissolving of mineral elements and at the same time decreases their bioaccessibility for the plants, which has particular importance in the case of heavy metals. Growth of $\mathrm{pH}$ value (and at the same time lowering of hydrolytic acidity) is caused by the process of lime coating which managed not only to neutralize acidity but also, as put forward by Greinert [1998], to remove free aluminum ions which are toxic for plants, from soil. Analyzing the level of salanity of material according to FAO, only in case of sample 8 - for which conductivity reached value $863.3 \mu \mathrm{S} / \mathrm{cm}$ - increased contents of soluble in water salt were observed. The value of con- 
Table 1. Physical characteristics of examined soils

\begin{tabular}{|c|c|c|c|c|}
\hline Sample & Contents of fraction >2 mm [\%] & Munsell soil color charts & Scent (intensity) & Granulometrical contents* \\
\hline 1 & 0.81 & 7.5 YR 5/3 brown & rotten (4) & clay loam (CL) \\
\hline 2 & 33.5 & 7.5 YR 6/2 pinkish grey & rotten (3) & clay loam (CL) \\
\hline 3 & 0.13 & 7.5 YR 5/2 brown & rotten (2) & clay loam (CL) \\
\hline 4 & 0.21 & 7.5 YR 6/4 light brown & rotten (4) & clay loam (CL) \\
\hline 5 & 1.37 & 7.5 YR 2.5/2 very dark brown & earth (3) & org. level / sand (S) \\
\hline 6 & none & 7.5 YR 7/2 pinkish grey & specific chemical (4) & clay loam (CL) \\
\hline 7 & 0.84 & 7.5 YR 3/1 very dark grey & specific chemical (4) & loamy sand (LS) \\
\hline 8 & 10.7 & 2.5 YR $8 / 3$ pale yellow & specific chemical (4) & loamy sand (LS) \\
\hline 9 & 5.08 & 7.5 YR 5/3 brown & rotten (3) & clay loam (CL) \\
\hline 10 & 24.3 & 7.5 YR 3/2 dark brown & rotten (2) & loamy sand (LS) \\
\hline
\end{tabular}

*according to USDA

Table 2. Physicochemical and chemical characteristics of soils

\begin{tabular}{|c|c|c|c|c|c|c|c|c|}
\hline \multirow[t]{2}{*}{ Sample } & \multirow{2}{*}{$\begin{array}{c}\mathrm{pH} \\
\mathrm{H}_{2} \mathrm{O} \\
\end{array}$} & \multirow{2}{*}{$\begin{array}{c}\text { EC } \\
\mu \mathrm{S} / \mathrm{cm} \\
\end{array}$} & $\mathrm{H}_{\mathrm{h}}$ & $\begin{array}{c}\text { Sum of exchangeable } \\
\text { alkaline cations }\end{array}$ & $\begin{array}{l}\text { Ammonia } \\
\text { nitrogen }\end{array}$ & $\begin{array}{c}\text { Nitrate } \\
\text { nitrogen }\end{array}$ & Chlorides & Sulfides \\
\hline & & & \multicolumn{2}{|r|}{$[\mathrm{cmol}(+) / \mathrm{kg}$ soil $]$} & \multicolumn{4}{|c|}{ [mg/kg d.m.] } \\
\hline 1 & 7.81 & 320.5 & 1.0 & 46.7 & 1.27 & 27.39 & 20.3 & 111.6 \\
\hline 2 & 7.14 & 191.5 & 1.0 & 27.4 & 0.41 & 14.20 & 15.2 & 10.1 \\
\hline 3 & 7.70 & 215.1 & 1.0 & 42.5 & 0.36 & 13.21 & 20.3 & 40.6 \\
\hline 4 & 7.62 & 370.4 & 1.8 & 48.6 & 0.13 & 30.32 & 15.2 & 10.1 \\
\hline 5 & 3.99 & 243.5 & 23.8 & 6.4 & 2.04 & 112.38 & 10.2 & 20.4 \\
\hline 6 & 7.52 & 248.2 & 1.4 & 18.4 & 0.25 & 11.10 & 20.2 & 90.8 \\
\hline 7 & 6.85 & 287.6 & 3.2 & 21.8 & 1.01 & 121.18 & 30.3 & 50.5 \\
\hline 8 & 7.13 & 863.3 & 2.0 & 46.6 & 14.21 & 101.47 & 40.6 & 1268.3 \\
\hline 9 & 6.58 & 263.1 & 2.6 & 23.5 & 0.46 & 116.92 & 10.2 & 76.2 \\
\hline 10 & 7.24 & 264.3 & 2.0 & 38.1 & 0.76 & 129.44 & 15.3 & 10.1 \\
\hline
\end{tabular}

ductivity reaches from 0.06 to $0.15 \%$ contents of salts in soil, which may present weak influence only on the highly sensitive species. According to the classification by FAO, the rest of samples do not exhibit salinity and, at the same time, negative reactions towards flora.

On the basis of all examined markings, point 8 containing industrial wastewaters, discharged probably from the nearest located factory. Disposed wastewaters, led towards a considerable increase in the contents of sulfides $(1268.3 \mathrm{mg} /$ $\mathrm{kg}$ d.m.), chlorides (40.6 mg/kg d.m.) ammonia nitrogen (14.21 mg/kg d.m.), nitrate nitrogen (101.5 mg/kg d.m.) and high electrolytic conductance (3.5 times larger than the background level). Chemically specific scent and colour also pointed towards polluted sample 8 . On the basis of the observations in the field, no other anthropogenic sources, which could lead to pollution of point 9 and 10, were found.

\section{Forms of iron}

In order to simulate natural transmission conditions of iron from the permanent phase into watery environment and evaluate its susceptibility to the leaching, three types of extractants (distilled water, $0,1 \mathrm{M} \mathrm{HCl}$ and $1 \mathrm{M}$ $\mathrm{HCl}$ ) with increased leaching power (Table 3 ) were used. The analysis confirmed that the amount of released metal grows together with increased force of used component. The content of leached forms of iron in the examined solutions was dependent on the granulometric composition of individual material, level of their pollution, physicochemical and chemical characteristic. During the extraction, iron presented considerable ability for leaching, under influence of water, because this metal is one of the most active chemical elements in soil [Kabata-Pendias and Pendias 1999]. 
After one hour of shaking, the largest amount of examined metal was found in ground extractions for the sand, and the smallest for the clay loam. Complete contents of metals in soil may lead only to determining the level of pollution, but do not point to the potential danger with the change of chemical characteristic of soil [Pusz 2013]. In the case of forms of leached iron $\mathrm{H}_{2} \mathrm{O}_{\text {dist }}$ in ratio to their complete contents, only in one sample - no. 7 - correlating participation of forms of metal slightly exceeded value of $1 \%$. In all the remaining samples, the afore-mentioned ratio was placed in the border between $0.004 \%$ (sample 1) and $0.384 \%$ (sample 5). In sample 1, participation of $\mathrm{Fe}$ extracted $\mathrm{H}_{2} \mathrm{O}_{\text {dist }}$ into $\mathrm{Fe}$ total was by order of magnitude smaller $(0.0004 \%)$ than in others, which was connected with $\mathrm{pH}$ value. The iron as given by Kabata-Pendias and Pendias [1999] in reduced and acidic conditions presents tendency towards solubility, but may precipitation in inaccessible form may only be possible alkaline environment.

In two samples (4 and 10) the lowest percentage participation of Fe extracted with $0,1 \mathrm{M}$ $\mathrm{HCl}$ into $\mathrm{Fe}$ in complete form did not exceed the value of $1 \%$. The ratio of forms in other materials exhibited large ability to change in the range from $1.2 \%$ (sample 5) to $55.3 \%$ (sample 7). While analyzing the results of iron leached with $1 \mathrm{M} \mathrm{HCl}$ in ratio to complete forms in all examined samples, high percent of participation of iron, which ranged from $7.2 \%$ (sample 5) to $76.8 \%$ (sample 2) was found. Table 4 presents the results of examination for three metals (cadmium, zinc and lead), including acceptable contents in soil and ground of substances possibly causing the risk, especially important for the protection of surface soil with different water permeability for soil and ground.

\section{Total concentration of cadmium, zinc and lead}

On the basis of grounds and buildings evidence the analyzed terrain was classified as forests, marked by symbol Ls, forested grounds with bushes planted on farm wastelands marked by symbol Lzr and barren land marked by symbol N. According to the regulation the Minister of the Environment of $1^{\text {st }}$ September 2016 on conduct of the assessment of contamination of the surface of the earth, the object of study was classified as ground group III. In the above-mentioned document, enclosure 1 p. 2 mentioned substances causing risk, particularly important for the protection of surface soil with acceptable contents of these substances in soil and ground $[\mathrm{mg} / \mathrm{kg}$ dry mass of earthly parts of soil $(<2 \mathrm{~mm})$ ] described for the depth exceeding $0.25 \mathrm{~m}$ BGL with division including groups of grounds, distinguished on the basis of their utilization and water permeability of soil and ground described by the value of filtration factor. In samples 1, 2, 3, 4, 6, 9 the value of water permeability of soil and ground was higher than $1 \times 10^{-7} \mathrm{~m} / \mathrm{s}$, but for other samples $(5,7,8$, 10) the value of water permeability was lower than $1 \times 10^{-7} \mathrm{~m} / \mathrm{s}$.

While analyzing table 4 , presenting the contents of examined metals (cadmium, zinc and lead) it may be stated that proper concentration of these metals exceed the acceptable concentration described in the above-mentioned regulation for the ground group III.

Table 3. Particular percentage of forms of iron into forms extracted with $1 \mathrm{M} \mathrm{HCl}$ and complete forms of iron

\begin{tabular}{|c|c|c|c|c|c|c|}
\hline \multirow{2}{*}{ Sample } & \multicolumn{2}{|c|}{ Contents of iron forms [mg/kg d.m. soil] after extraction } & \multicolumn{3}{c|}{ Percentage [\%] } \\
\cline { 2 - 7 } & $\mathrm{H}_{2} \mathrm{O}$ & $0.1 \mathrm{M} \mathrm{HCl}$ & $1 \mathrm{M} \mathrm{HCl}$ & $\mathrm{H}_{2} \mathrm{O} / \mathrm{Fe}$ total & $0.1 \mathrm{M} \mathrm{HCl} / \mathrm{Fe}$ total & $1 \mathrm{M} \mathrm{HCl} / \mathrm{Fe}$ total \\
\hline 1 & 1.0 & 8114.8 & 64918.7 & 0.0004 & 3.0 & 23.9 \\
\hline 2 & 4.1 & 8112.1 & 62869.2 & 0.005 & 9.9 & 76.8 \\
\hline 3 & 6.1 & 8534.6 & 44704.8 & 0.010 & 14.2 & 74.5 \\
\hline 4 & 28.3 & 40.4 & 22237.3 & 0.039 & 0.1 & 30.8 \\
\hline 5 & 98.1 & 306.5 & 1838.9 & 0.384 & 1.2 & 7.2 \\
\hline 6 & 6.1 & 6054.8 & 32292 & 0.004 & 3.6 & 19.0 \\
\hline 7 & 44.4 & 2221.7 & 2726.6 & 1.106 & 55.3 & 67.9 \\
\hline 8 & 23.3 & 2029.3 & 26381.2 & 0.020 & 1.7 & 22.3 \\
\hline 9 & 40.7 & 5286.6 & 40666.1 & 0.034 & 4.5 & 34.4 \\
\hline 10 & 48.9 & 428.1 & 44846.2 & 0.043 & 0.4 & 39.8 \\
\hline
\end{tabular}


Table 4. Contents of cadmium, zinc and lead in soils [mg/kg d.m.]

\begin{tabular}{|c|c|c|c|c|c|c|c|c|c|c|}
\hline \multirow{2}{*}{ Metal } & \multicolumn{10}{|c|}{ Sample } \\
\hline & 1 & 2 & 3 & 4 & 5 & 6 & 7 & 8 & 9 & 10 \\
\hline Cadmium & 8.11 & 6.08 & 4.57 & 7.08 & 4.90 & 4.14 & 1.21 & 5.78 & 5.9 & 8.36 \\
\hline Group III & 5 & 5 & 5 & 5 & 3 & 5 & 3 & 3 & 5 & 3 \\
\hline Zinc & 444.1 & 134.2 & 472.1 & 105.5 & 112.2 & 87.2 & 60.7 & 150.6 & 159.3 & 345.2 \\
\hline Group III & 500 & 500 & 500 & 500 & 300 & 500 & 300 & 300 & 500 & 300 \\
\hline Lead & 84.6 & 60.8 & 339.7 & 58.6 & 29.7 & 41.6 & 43.5 & 58.2 & 59.5 & 97.7 \\
\hline Group III & 300 & 300 & 300 & 300 & 100 & 300 & 100 & 100 & 300 & 100 \\
\hline
\end{tabular}

The concentration of cadmium exceeded the acceptable value of $3 \mathrm{mg} / \mathrm{kg}$ in three samples 5,8 and 10 and permissible value of $5 \mathrm{mg} / \mathrm{kg}$ accepted for the lower water permeability in four samples 1, 2, 4 and 9 which corresponds to $70 \%$ of the tested samples. For the two other metals, exceeded limit was found in two points for zinc in sample 10 and for lead in sample 3 which may be connected with the influence of factory activity in the neighboring location. The examined grounds presented neutral $\mathrm{pH}$ which is directly connected with the metal activity in the ground. With base and alkaline $\mathrm{pH}, \mathrm{Cd}$ and $\mathrm{Zn}$ are released into ground solutions because of their displacement by the inorganic ions [Kabata-Pendias and Pendias 1999]. To sum up, part of pollutants (iron) are the direct results from the dumping of waste and are connected with the same character of material and their resources in organic matter. These objects, partly secured by lime coating (against leaching of heavy metal, especially iron) should be treated in further processes of recultivation and land development because of the progressing erosion on the slope. The size of the objects may suggests that further land development towards recreational type, for example by creating all-year-round ski slope or green area holding places (like theme parks) or following history of dumping grounds of Bełchatów mine, arranging wind farms on the top, may be possible. It is worth mentioning the possibility of conducting additional geological examinations that would allow precise description of geochemical forms, in which iron is located on the objects, for the purpose of qualification as anthropogenic secondary deposit that still gathers useful mineral.

\section{CONCLUSIONS}

1. On the examined waste heaps, chemical degradation and degradation of ecological structure occurs simultaneously with the geomechanical degradation which is the consequence of deformation of natural soil formations and density of soil layers.

2. Overbalance of nitrate nitrogen over ammonia nitrogen in the collected samples shows the prevalence of nitrification processes over ammonification processes. Even though the structures of most soils produce difficulty for gas exchange with atmosphere (clay loam) sufficient oxygen conditions exist for the growth of nitrogen bacteria, which use the carbons in soil as source of coal.

3. According to regulation of the Minister of the Environment of $1^{\text {st }}$ September 2016 on conduct of the assessment of contamination of the surface of the earth, the examined location was classified as ground group III for which the exceeded level of permissible cadmium was found in $70 \%$ of samples and in $10 \%$ of samples for zinc and lead.

4. Iron content in the filtrates after extraction in $\mathrm{H}_{2} \mathrm{O}_{\text {dist }}$ was increasing together with the force of used extractant and acidification of soils.

5. Proceeding water erosion of the slope of object $\mathrm{B}$ is the consequence of improperly profiled steep slopes which are the cause of uncontrolled flow of rain waters, lack of flora and dense, fine grained structure of soil, unable to perform the effective filtration of water. Infiltration of water into the ground creates deep ril- marks in soil which in time of dry periods function as additional routes for landslides. 


\section{REFERENCES}

1. Adamczyk M., Pastuszka S. 1984. Starachowicezarys dziejów. Ludowa Spółdzielnia wydawnicza, Warszawa.

2. Gabzdyl W. 1999. Geologia złóż. Wydawnictwo Politechniki Śląskiej, Gliwice.

3. Glapa W., Korzeniowski J.I. 2005. Mały leksykon górnictwa odkrywkowego. Wydawnictwa i Szkolenia Górnicze Burnat \& Korzeniowski, Wrocław.

4. Gorlach E., Mazur T. 2001. Chemia rolna - Podstawy żywienia i zasady nawożenia roślin. Wydawnictwo Naukowe PWN, Warszawa.

5. Greinert A. 1998. Przewodnik do ćwiczeń z gleboznawstwa i ochrony gleb. Wydawnictwo Politechniki Zielonogórskiej.

6. Hillel D. 2008. Soil in the Environment. Crucible of Terrestrial Life. Elsevier Inc. NY.

7. Józefaciuk A., Józefaciuk C. 1996a. Erozja i melioracje przeciwerozyjne. Państwowa Inspekcja Ochrony Środowiska, Warszawa.

8. Józefaciuk A., Józefaciuk C. 1996b. Mechanizm i wskazówki metodyczne badania procesów erozji. Państwowa Inspekcja Ochrony Środowiska, Warszawa.

9. Kabata-Pendias A., Pendias H. 1999. Biogeochemia pierwiastków śladowych. Wydawnictwo Naukowe PWN, Warszawa.

10. Karczewska A. 2012. Ochrona gleb i rekultywacja terenów zdegradowanych. Wydawnictwo Uniwersytetu Przyrodniczego we Wrocławiu, Wrocław.

11. Kosacka H., Niezgoda I., Suska-Jakubczak E., Tkaczyk P. 2007. Określenie uwarunkowań gle- bowych gminy Sosnowica w kontekście innowacyjnego planu rozwoju gminy. Okręgowa Stacja Chemiczno-Rolnicza w Lublinie, Lublin.

12. Maciejewska A. 2000. Rekultywacja i ochrona środowiska w górnictwie odkrywkowym. Oficyna Wydawnicza Politechniki Warszawskiej, Warszawa.

13. Ostrowska A., Gawliński S., Szczubiałka Z. 1991. Metody analiz i oceny właściwości gleb i roślin katalog. Wydawnictwo IOŚ, Warszawa.

14. Pancewicz A. 2009. Hałdy - kłopot czy szansa?. Nauka Przyroda Technologie, Dział: Ogrodnictwo, Zeszyt 1, Tom 3.

15. Pusz A. 2013. Ocena skuteczności metod remediacji gleb zanieczyszczonych metalami dla potrzeb rekultywacji zdegradowanych terenów przemysłowych. Oficyna Wydawnicza Politechniki Warszawskiej, Warszawa.

16. Rozporządzenie Ministra Środowiska z dnia 1 września 2016 r. w sprawie sposobu prowadzenia oceny zanieczyszczenia powierzchni ziemi [Dz.U. 2016 poz. 1395].

17. Siuta J., Makowiecki K., Zielińska A. 1985. Degradacja ziemi. Instytut Kształtowania Środowiska, Warszawa.

18. Uggla H. 1977. Gleboznawstwo rolnicze. Państwowe Wydawnictwo Naukowe, Warszawa.

19. Uggla H. 1979. Gleboznawstwo leśne. PWRiL, Warszawa.

20. Ustawa z dnia 3 lutego 1995 r. o ochronie gruntów rolnych i leśnych [Dz.U. $1995 \mathrm{Nr} 16$ poz. 78] z póź. zm.

21. Ustawa z dnia 13 kwietnia 2007 r. o zapobieganiu szkodom w środowisku i ich naprawie [Dz.U. 2007 nr 75 poz. 493] z póź. zm. 